\title{
THE LETTERS OF
}

\section{Henry Wadsworth Longfellow}

\author{
VOLUME VI \\ I $875-1882$
}





\title{
THE LETTERS OF \\ Henry Wadsworth Longfellow
}

\author{
EDITED BY \\ Andrew Hilen \\ VOLUME VI \\ I $875-1882$
}

The Belknap Press of Harvard University Press

Cambridge, Massachusetts, and London, England 1982 
Copyright $(\mathcal{C} 1982$ by the President and Fellows of Harvard College All rights reserved

Printed in the United States of America

\section{Library of Congress Cataloging in Publication Data}

Longfellow, Henry Wadsworth, 1807-1882.

The letters of Henry Wadsworth Longfellow.

Includes bibliographies and indexes.

Contents: v. 1. 1814-1836-v. 2. 1837-1843-[etc.]

v. 6. $1875-1882$.

1. Longfellow, Henry Wadsworth, 1807-1882-Corre-

spondence. 2. Poets, American-19th century-Corre-

spondence. I. Hilen, Andrew R., 1913- ed.

II. Title.

$\mathrm{PS}_{2281} \mathrm{~A}_{3} \mathrm{H}_{5} \quad 811^{\prime} \cdot 3 \quad 66-18248$

ISBN $0-674-52728-3 \quad$ AACR2

ISBN $0-674-52729-1$ 